Original Research Paper

\title{
Modeling of Some Dairy Performance Indices on Milk Somatic Cell Count in Holstein Dairy Cows
}

\author{
${ }^{1}$ Ahmed Dawod, ${ }^{2}$ Sherif Shawky, ${ }^{3}$ Tamer M. Abdel-Hamid, \\ ${ }^{4}$ Mohamed Fathalla, ${ }^{2}$ Ibrahim Abu-Alya and ${ }^{2}$ Said Fathalla \\ ${ }^{1}$ Department of Husbandry and Animal Wealth Development, \\ Faculty of Veterinary Medicine, University of Sadat City, Menofia, Egypt \\ ${ }^{2}$ Department of Physiology, Faculty of Veterinary Medicine, University of Sadat City, Menofia, Egypt \\ ${ }^{3}$ Animal Wealth Development Department, Faculty of Veterinary Medicine, Zagazig University, Sharkia, Egypt \\ ${ }^{4}$ Animal Husbandry and Animal Wealth Development Department, \\ Faculty of Veterinary Medicine, Alexandria University, Alexandria, Egypt
}

\author{
Article history \\ Received: 19-06-2019 \\ Revised: 17-09-2019 \\ Accepted: 23-10-2019 \\ Corresponding Author: \\ Ahmed Dawod \\ Department of Husbandry and \\ Animal Wealth Development, \\ Faculty of Veterinary \\ Medicine, University of Sadat \\ City, Menofia, Egypt \\ Tel: +201111505240 \\ Email: adawod@vet.usc.edu.eg
}

\begin{abstract}
This study was conducted to evaluate the direct and the indirect standardized effects of some dairy performance parameters (days dry, lactation length, parity, total milk yield and 305-day milk yield) on the milk Somatic Cell Count (SCC) of Holstein cows throughout modeling of these variables with the path analysis technique. During studying 617 Holstein cows were enrolled in the experiment with the average Days in Milk (DIM) of $15 \pm 7.14$ and still in the trial till the end of their lactation length. Milk samples were taken from each cow every three months; then, the fresh milk samples subjected to somatic cell counting via automatic cell counter. Other data of days dry, lactation length, parity, total and actual 305-day milk yields obtained from the dairy farm recording system (Dairycomp). After collection of all data, the data entered to AMOS software program version 24 to build a path model among days dry, lactation length, parity as independent variables and total, 305-day milk yields as intermediate transitional variables and milk SCC as a dependent variable. The study revealed that the SCC was directly affected by lactation length, total and 305-day milk yields, while it indirectly affected with total milk yield. Moreover, the overall standardized effect of the total milk yield on the milk SCC was week as a result of the negative direct effect -0.173 neutralized with another positive indirect one 0.229 .
\end{abstract}

Keywords: Somatic Cell Count, Modelling, Dairy Cows, Parity, Holstein Friesian

\section{Introduction}

Milk quality and udder health are the most critical factors governing the dairy farm's profitability. The customers of the dairy products are seeking the products with attractive constituents and proficient characters, as milk charges were reliant on its composition. Therefore, dairy farmers have modified their management practices to obtain high milk quality in combination with superior animal welfare (Nasr, 2016). Somatic cells are an essential milk constituent used to govern the mammary gland health and milk quality (Richoux et al., 2014). The increasing of the Somatic Cell Count (SCC) in milk is associated with hazardous effects on milk quality, as the milk with high SCC has reduced milk fat, protein, lactose and minerals (Lindmark et al., 2006). In consequence of that, the milk SCC is commonly used to calibrate the payments to dairy producers (Pirisi et al., 2007).

The main two components of the milk somatic cell count are leukocytes, which ranged from 75 to $85 \%$ and epithelial cells, which reach up to $15-25 \%$ (Barrett, 2007). The elevation of the SCC combined with a reduction in the synthetic power of the udder (Harmon, 1994). Furthermore, the predominant adverse effects of the high SCC in milk associated with shorter life spans of the dairy animal together with negative organoleptic characters of the dairy milk and its end products, this caused by the enzymatic actions of the somatic cells (Töpel, 2004).

Advancement of the parities led to a steady increased in SCC (Natzke et al., 1972; Yang et al., 2013). Linearly, Nasr and El-Tarabany (2017) detected an elevation of SCC with either parities progress or aging of 
the cow. This elevation could be as a result of the high incidence of permanent glandular impairment from retreating of infections (Natzke et al., 1972). In contrast, Sevi et al. (2000) suggested that the parities had no significant effect on SCC. Moreover, the daily variation in milk SCC can be extensive even for healthy cows (Schepers et al., 1997).

Additionally, proper milking hygiene and the education level of employees in dairy farms are the most critical factors affecting the milk SCC (Yalçın et al., 2010). In concurrent work, the path analysis was used to build a path model to quantify the effect of some dairy performance variables (days dry, lactation length, parity number, total and actual 305-day milk yields) on milk SCC. The path model would be evaluated the relative contribution of each component with its direct and indirect effects on milk yield and SCC.

\section{Materials and Methods}

\section{Ethical Statement}

The study was assessed and agreed by the Animal Care and Welfare Committee Ethics, Sadat City University, Egypt.

\section{Animals and Experimental Design}

The study was conducted in a private modern dairy farm located in Giza provenance, Egypt during the period from January 2017 to February 2019, with atmospheric temperature ranged from 17 to $42^{\circ} \mathrm{C}$ and relative humidity ( $\mathrm{Rh} \%$ ) from 33 to $60 \%$. The cows were high yielding dairy cows with average milk production of 9000 Liters/season and 2.18 parity numbers (range 1-9 parity). During studying 617 Holstein cows were enrolled in the experiment. The cows were enrolled in the research from $15 \pm 7.14$ Days in Milk (DIM) till the end of their lactation phase. The cows were fed Total Mixed Ration (TMR) three times per day. The ration was adjusted to the nutritional needs of the dairy Holstein breed. The diet (DM/kg per day) based on corn silage (18.0), grounded corn (7.8), alfalfa hay (6.0), soybean $44 \%$ (2.3), wheat bran (3.2), dried pulp root (2.8), rice bran (2.8), cottonseed (2.8), sunflower meal (1.2), beaker yeast (0.10) and a mineral and vitamin supplement. The ration crude protein content was adjusted to $18 \%$ on the dry matter basis. The animals housed within free-stall colony pens with free-choice water supply.

\section{Milking and Milking Equipment}

The cows milked in a herringbone parlor three times per day with equal milking intervals of $8 \mathrm{~h}$. The cows milked via air-pipeline milking system equipped with automatic take-off systems and automated recording systems (ALPRO, DeLaval, Kansas City, Missouri, USA) with monovac (same vacuum level throughout milking), a pulsation ratio of 70/30, a pulsation rate of 60 cycles/min and a system vacuum of $42 \mathrm{kPa}$. Periodical udder health examination followed with rigid milking hygiene. The cows which suffered from generalized or udder health problems culled from the trial.

\section{Measurements}

Individual milk samples were collected once every three months from each cow throughout lactation. Samples were taken fresh from the automatic milking system in $50 \mathrm{~mL}$ milk sampling tubes; then the milk samples were subjected to somatic cell counting via a fluoroopto- electronic counter (Fossomatic TM FC, Foss, Hillerød, Denmark). SCC was within the average level of the healthy mammary gland and it was less than 100000 cells/ml (Bradley and Green, 2005). Data of days dry, lactation length, parity, total and actual 305-day milk yield gained from the computer recording system (Dairycomp).

\section{Statistical Analysis}

The data of days dry, lactation length, parity, total milk yield, 305-day milk yield and SCC enrolled in the statistical analysis after a complete examination of the data. The dairy record which had data losses more than $10 \%$ excluded from the further statistical analysis. The SCC data of each dairy cow were logarithmically transformed to obtain normal distributed values. The logarithmically processed data of the SCC of each cow grouped in one geometric pooled mean which used as overall SCC average in the further path analysis. Besides, the UNIVARIATE procedure was used to determine outlier cows. Records that were $>2.5$ standard deviations from the mean for 305-day milk yield was considered outliers and excluded from the analyses. This editing procedure resulted in 509 records for the analysis. The verifying of normality of the data done via the Kolmogorov-Smirnov test, which revealed that no variables differed significantly from the normal distribution $(p>0.05)$. While, the homogeneity of the variance was done via Levene's test, as all variables were confirmed to be homogenous. The path analysis was performed via SPSS software package version 24 (IBM Corp, 2016) together with AMOS software package version 24 to build a path model.

The path analysis used to build a conceptual model between SCC as the dependent variable, 305-day milk yield and total milk yield as intermediate variables and lactation length, parity and days dry as independent predictor variables. After complete data processing and screening, the data was entered to AMOS, to conduct the path analysis.

The process of construction of the hypothetical model performed according to correlation matrix and literature suggested. The method of building up arranged from the independent variables (days dry, lactation length and parity to intermediate variables (total and actual 305-day milk yields) then finally to the dependent variable (SCC). 


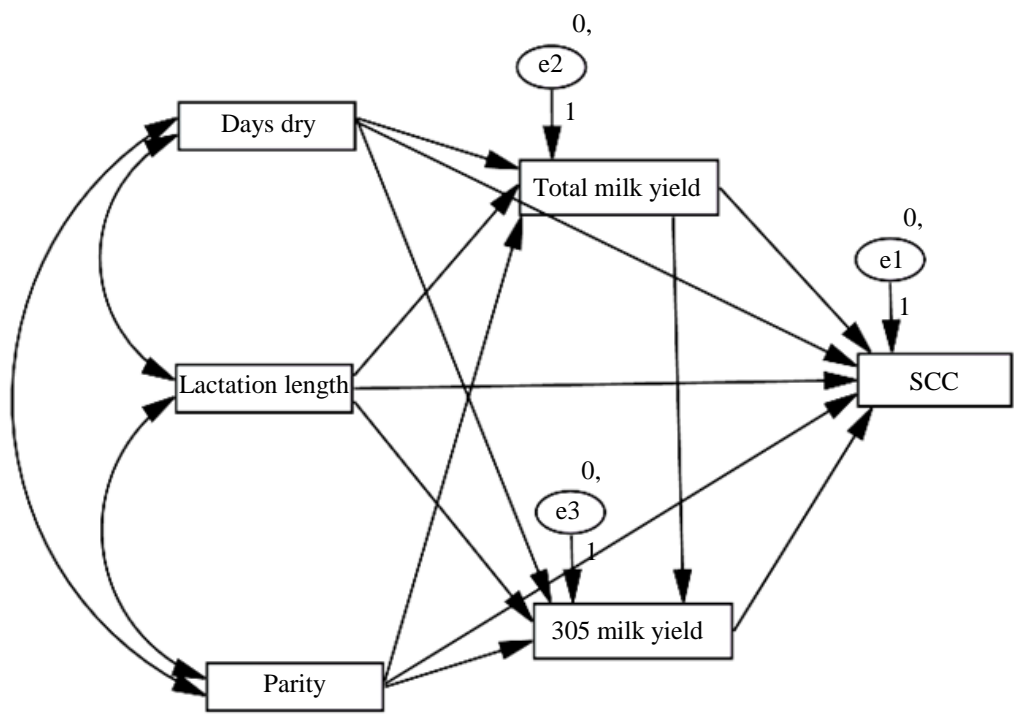

Fig. 1: The suggested path model

Table 1: The correlation matrix of the dairy performance indices and somatic cell count

\begin{tabular}{lllllll}
\hline Parameters & Lactation length & Days dry & Parity number & Total milk yield & 305-day milk yield & SCC \\
\hline Lactation length & 1 & & & & & \\
Days dry & 0.069 & 1 & & & & \\
Parity number & -0.005 & $0.139^{* *}$ & 1 & 1 & & \\
Total milk yield & $0.839^{* *}$ & 0.083 & 0.018 & $0.365^{* *}$ & 1 \\
305-day milk yield & $0.175^{* *}$ & $0.153^{* *}$ & -0.099 & $0.248^{* *}$ & $0.365^{* *}$ & 1 \\
SCC & $0.310^{* *}$ & -0.052 & -0.081 & \\
\hline
\end{tabular}

**Correlation is significant at the 0.01 level (2-tailed). SCC: somatic cell count

The model construction process resulted in the following suggested model (Fig. 1) then the estimation of the model was run in AMOS.

After the initial building process had achieved and the model tended to be modified with the support of the modification indexes provided from AMOS software from the higher value to the smaller one sequentially, to obtain an ideal model. The model fit estimation performed after each time of modification. This sequence was repeated and didn't stop until the AMOS provides no modification index. The non-significant paths were removed one by one and followed by checking of any more modification index provided each time.

\section{Results}

\section{The Correlation Matrix of the Dairy Performance Indices and Somatic Cell Count}

The correlation matrix among different study variables revealed no correlation between days dry and the SCC (Table 1). The same trend appeared in the relationship between the parity and the SCC. In contrast, the milk SCC possessed high significant correlation with lactation length, total milk yield and 305-day milk yield $(0.310, \quad 0.248, \quad 0.365$, respectively) at $(\mathrm{p} \leq 0.01)$. Moreover, the lactation length was in highly significant correlation with total and 305- day milk yields (0.839 and 0.175 , respectively) at $(\mathrm{p} \leq 0.01)$. Similarly, days dry correlated with both parity and 305-day milk yield with correlation coefficients of 0.139 and 0.153 , respectively $(\mathrm{p} \leq 0.01)$. Furthermore, total milk yield was strongly correlated with 305-day milk yield with a correlation coefficient of 0.365 at $(\mathrm{p} \leq 0.01)$.

The previous results indicate that none of the observed variables showed a significant linear correlation higher than $0.9(r>0.90)$ among each other. Thus showed no multi-collinearity would arise in the path model and excellent fit would be obtained (Tabachnick and Fidell, 2007).

\section{Dairy Performance Indices and Somatic Cell Count Path Model}

Path analysis in concurrent work was used to build conceptual model between SCC as a dependent variable, 305-day milk yield and total milk yield as intermediate variables and lactation length, parity and days dry as independent predictor variables. 


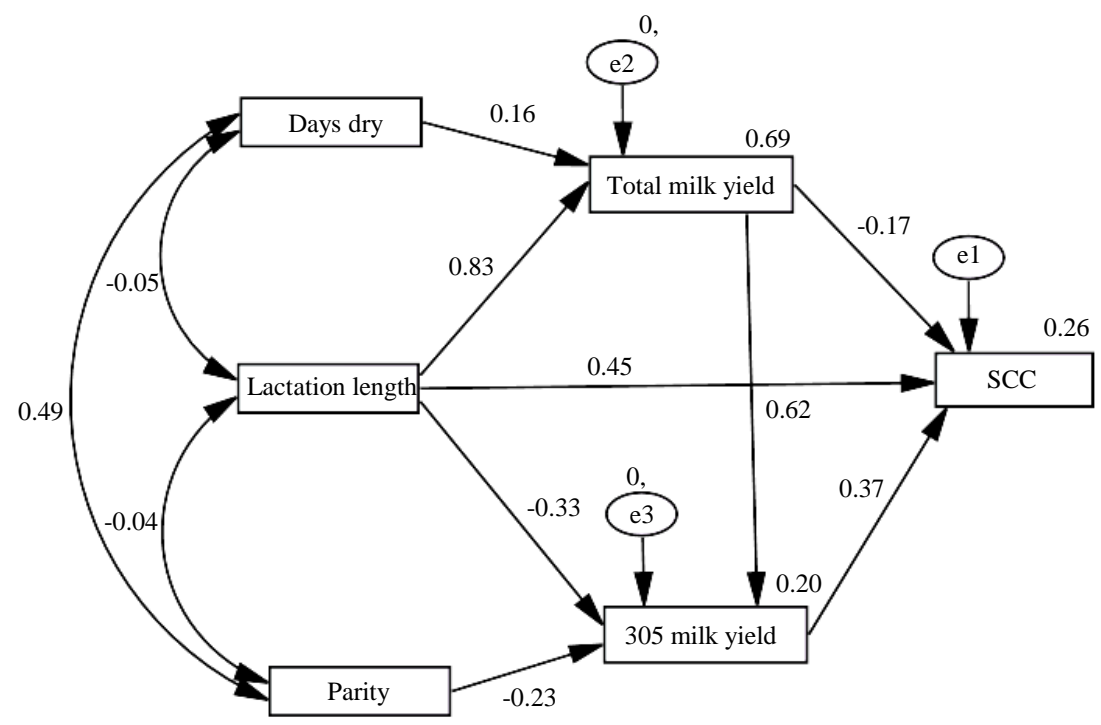

Fig. 2: The path model with estimated beta load and explained variance of the dairy performance indices and somatic cell count

Table 2: The model fit indexes of the dairy performance indices and somatic cell count in path model

\begin{tabular}{|c|c|c|c|c|c|}
\hline \multirow[b]{2}{*}{ Model fit indexes } & \multirow[b]{2}{*}{$\begin{array}{l}\text { Value of Fit } \\
\text { index for the } \\
\text { proposed model }\end{array}$} & \multicolumn{3}{|c|}{ Measures indicate the goodness of fit } & \multirow[b]{2}{*}{ Reference } \\
\hline & & $\begin{array}{l}\text { Index } \\
\text { range }\end{array}$ & $\begin{array}{l}\text { Ideal } \\
\text { index range }\end{array}$ & $\begin{array}{l}\text { The index } \\
\text { value of the } \\
\text { complete fit }\end{array}$ & \\
\hline Chi-square $\left(\chi^{2}\right)$ & 4.207 & \multirow{3}{*}{\multicolumn{3}{|c|}{$\begin{array}{l}\text { The value of Chi-square } \\
\text { is not significant at }(\mathrm{P} \geq 0.05)\end{array}$}} & \multirow[t]{3}{*}{ Barrett (2007) } \\
\hline Degree of freedom (df) & 4 & & & & \\
\hline Chi-square significance level & 0.379 & & & & \\
\hline Chi-square ratio (Chi-square/ df) & 1.052 & $>0.00$ & $\leq 2$ & $0-1$ & Tabachnik and Fidel (2007) \\
\hline $\begin{array}{l}\text { Root mean square error } \\
\text { of approximate (RMSEA) }\end{array}$ & 0.009 & $0-1$ & $\leq 0.07$ & 0 & Steiger (2007) \\
\hline \multicolumn{2}{|l|}{ Expected cross validation index (ECVI) } & & & & \\
\hline ECVI for saturated model & $\begin{array}{l}0.080 \\
0.086\end{array}$ & \multicolumn{2}{|c|}{$\begin{array}{l}\text { ECVI for the model } \leq \text { ECVI for } \\
\text { the saturated model }\end{array}$} & & Tabachnick and Fidell (2007) \\
\hline Normal fit index (NFI) & 0.996 & $0-1$ & $\geq 0.95$ & 1 & $\mathrm{Hu}$ and Bentler (1999) \\
\hline Non-normed fit index (TLI) or (NNFI) & 0.999 & $(\leq 0)-(\geq 1)$ & $\geq 0.95$ & 1 & \\
\hline Relative fit index (RFI) & 0.981 & $0-1$ & $\geq 0.95$ & 1 & \\
\hline Incremental fit index (IFI) & 1 & $0-1$ & $\geq 0.95$ & 1 & \\
\hline Comparative Fit Index (CFI) & 1 & $0-1$ & $\geq 0.95$ & 1 & \\
\hline Standardized Root Mean & 0.05 & $0-1$ & $\leq 0.08$ & 0 & \\
\hline Square Residual (SRMR) & & & & & \\
\hline
\end{tabular}

\section{The Model Fit Indexes of the Dairy Performance Indices and Somatic Cell Count in Path Model}

Parameter loading (Beta), explained variance $\left(\mathrm{R}^{2}\right)$ was determined for the path model (Fig. 2) as well as the model fit indexes (Chi-square $\left(\chi^{2}\right)$, Comparative Fit Index (CFI), Normal Fit Index (NFI), Non-Normal Fit Index (TLI), Incremental Fit Index (IFI), Relative Fit Index (RFI), Root Mean Square Error of Approximate (RMSEA) and Standardized root mean square residual (SRMR) with their $p$-values reported in (Table 2). The path model fit indexes had suitable fit values for the original data, as the chi-square was not significant at $(\mathrm{p} \leq 0.05)$ and the chi-square/df ratio is less than 2. Also, the values of NFI, TLI, RFI, IFI and CFI were $>0.95$, which indicate good model fit.
The values of SRMR and RMSEA were 0.05, 0.001, respectively and these values indicated good model fit as they were less than those of their ideal range 0.08 , 0.07 , respectively.

The Standardized Beta Loads of the Dairy Performance Indices and Somatic Cell Count in Path Model

The total and 305-day milk yield and lactation length significantly influenced the SCC (Table 3), as lactation length was strongly influenced the milk SCC with standardized beta load of 0.446 followed by 305 day milk yield with beta load of 0.367 and finally the total milk yield had negatively influenced the SCC with standard beta load of -0.173 . 
Table 3: Standardized beta load between the dairy performance indices and somatic cell count in path model Performance indices

\begin{tabular}{llccccc}
\hline Independent & Dependent & Estimated beta load & Standard error & Critical ratio & P-value & Significance \\
\hline Days dry & Total milk yield & 0.157 & 1.436 & 6.899 & 0.000 & Yes \\
Lactation length & Total milk yield & 0.826 & 0.433 & 36.424 & 0.000 & Yes \\
Lactation length & 305-day milk yield & -0.327 & 1.107 & -5.033 & 0.000 & Yes \\
Parity & 305-day milk yield & -0.226 & 56.763 & -6.047 & 0.000 & Yes \\
Total milk yield & 305-day milk yield & 0.623 & 0.058 & 9.599 & 0.000 & Yes \\
Total milk yield & SCC & -0.173 & 0 & -2.637 & 0.008 & Yes \\
305-day milk yield & SCC & 0.367 & 0 & 9.538 & 0.000 & Yes \\
Lactation length & SCC & 0.446 & 0.001 & 7.127 & 0.000 & Yes \\
\hline
\end{tabular}

SCC: Somatic Cell Count

Table 4: Correlation matrix between different study independent variables

\begin{tabular}{lllllll}
\hline Performance indices & Estimate correlation & Standard error & Critical ratio & P-value & Significance \\
\hline Days dry & Lactation length & -0.055 & 231.32 & -1.368 & 0.171 & No \\
Parity & Days dry & 0.494 & 2.894 & 11.053 & 0.001 & Yes \\
Parity & Lactation length & -0.041 & 8.622 & -1.028 & 0.304 & No \\
\hline
\end{tabular}

Table 5: Explained variances (squared multiple correlations) for the study intermediate and dependent variables

\begin{tabular}{ll}
\hline Parameters & Estimate explained variance \\
\hline Total milk yield & 0.693 \\
305-day milk yield & 0.195 \\
SCC & 0.257 \\
\hline
\end{tabular}

SCC: somatic cell count

Table 6: Standardized total effects between different study variables

\begin{tabular}{llllll}
\hline Parameters & Lactation length & Days dry & Parity & Total milk yield & 305-day milk yield \\
\hline Total milk yield & 0.826 & 0.157 & 0 & 0 & 0 \\
305-day milk yield & 0.188 & 0.098 & -0.226 & 0.623 & 0 \\
SCC & 0.373 & 0.009 & -0.083 & 0.056 & 0.367 \\
\hline
\end{tabular}

SCC: somatic cell count

Lactation length, parity and total milk yield possessed significant relationships with 305-day milk yield. The most substantial positive influence was attained between the total and 305-day milk yield with a standardized beta load of 0.623 , while the lowest impact was achieved in the parity as it influenced the 305-day milk yield with a negative beta load of -0.226 . Additionally, the lactation length had a negative effect on 305-day milk yield with a standardized beta load of 0.327 . Total milk yield greatly influenced with lactation length with a beta load of 0.826 followed with days dry with a beta load of 0.157 .

The correlation matrix revealed from the path model (Table 4), it was proof that the only significant positive correlation achieved between days dry and the parity with correlation coefficient (r) of 0.494 .

The variance explained obtained from the path model was 0.693 for the total milk yield variance, as this means the model could explain about 0.693 from the total variation of the total milk yield (Table 5). Also, the path model succeeded to explain nearly 0.257 of the milk SCC variation, while the model could explain only 0.195 from the 305-day milk yield variation.
One of our exciting results is the total, direct and indirect effects of independent variables on intermediated and dependent variables (Tables 6, 7 and 8). As, lactation length influenced the total milk yield with only direct effect by a standardized beta load of 0.826 , while it affected the 305-day milk yield with a standardized total effect of 0.188 about -0.327 of this effect was direct effect and 0.515 was indirect effect, as the direct negative effect masks some of the indirect ones. Similarly, the lactation length affected SCC with a total effect of 0.373 . This summed total value outcomes from the neutralization of the lactation length direct effect by 0.446 with another indirect one -0.074 on the SCC.

Days dry also have influenced the total milk yield only by the direct effect with a standardized beta load of 0.157 . However, it affected the 305-day milk yield and SCC only by the indirect route with a standardized beta load of 0.098 and 0.009 , respectively. The parity number affected the 305-day milk yield directly with a standardized beta load of -0.226 , while it influenced the SCC indirectly by a standardized beta load of -0.083 throughout the 305-day milk yield as an intermediate variable. Additionally, the 305-day milk yield was directly affected the SCC by a standard beta load of 0.367 . 
Table 7: Standardized direct effects between different study variables

\begin{tabular}{llllll}
\hline Parameters & Lactation length & Days dry & Parity & Total milk yield & 305-day milk yield \\
\hline Total milk yield & 0.826 & 0.157 & 0 & 0 & 0 \\
305-day milk yield & -0.327 & 0 & -0.226 & 0.623 & 0 \\
SCC & 0.446 & 0 & 0 & -0.173 & 0.367 \\
\hline SCC: & & & &
\end{tabular}

SCC: Somatic Cell Count

Table 8: Standardized indirect effects between different study variables

\begin{tabular}{llllll}
\hline Parameters & Lactation length & Days dry & Parity & Total milk yield & 305-day milk yield \\
\hline Total milk yield & 0 & 0 & 0 & 0 & 0 \\
305-day milk yield & 0.515 & 0.098 & 0 & 0 & 0 \\
SCC & -0.074 & 0.009 & -0.083 & 0.229 & 0 \\
\hline SCC: Som & & &
\end{tabular}

SCC: Somatic Cell Count

\section{Discussion}

The present study proposed to evaluate either the direct or the indirect effects of some dairy performance parameters (days dry, lactation length, parity, total and 305-day milk yields) on SCC in Holstein milk via path modeling technique. The results revealed that the 305day milk yield and the total milk yield were strongly affected by lactation length. Additionally, the path model showed strong positive effects of either 305-day milk yield or total milk yield on SCC. These findings were following the previous reports of (Kadarmideen, 2004). The previous result might be due to the genetic correlation between the milk production and SCC (Carlén et al., 2004; Kadarmideen, 2004), in addition to the harmful effects of high milk yield on immunity and health of the dairy cows. On the contrary, conflict trials recorded a negative correlation between milk yield and SCC is well documented by many authors (Jia-Zhong et al., 2010; Yang et al., 2013; Teleb et al., 2014; Nasr and El-Taurbany, 2017). Our results contrast with several previous studies, but significant differences among herds and study methodologies should note.

The path model revealed a positive effect of the lactation length on the SCC via both the direct and the indirect routes. The findings indicated the elevation of SCC accompanied with via long lactation length. These results agreed with those of (Kennedy et al., 1982; Sheldrake et al., 1983). Dohoo and Meek (1982) reported higher SCC during the late stage of lactation in comparison to early and mid-stages. Moreover, the SCC was most elevated soon after calving, dropped quickly during the period from 25 and 45 DIM and then elevated gradually during the course of the rest of the lactation cycle (Kennedy et al., 1982). Strong correlation had been noted between SCC and stage of lactation in healthy dairy cows, as the SCC increased with the progress of the DIM (Sheldrake et al., 1983).

The current study suggested that the parity had a direct negative effect on the 305-day milk yield. This result was in agreement with the findings of (Gonçalves et al., 2018).
Also, the results suggested that the total milk yield affected the 305-day milk yield directly with strong positive effect. This finding was inconsistent with (Nasr and El-Tarabany, 2017).

The parity possessed week negative effect on the SCC via the indirect route only. This week effect attained throughout the negative effect of parity on the 305-day milk yield. These findings match those of (Gonçalves et al., 2018). Laevens et al. (1997) and Sevi et al. (2000) can't find any significant effect of parity, stage of lactation and their interaction on SCC in bacteriological free cows. In contrast, Yang et al. (2013) reported that the increase of the parity number accompanied by a gradual increase in SCC. Other researchers proofed that the higher SCC in the dairy cows attained during the second (Kiiman, 1998) and the third parities (Eyduran et al., 2005).

Regarding the effect of the days dry on the milk $\mathrm{SCC}$, the path model revealed a positive indirect effect of the days dry on the milk SCC. In contraries, Khazanehei et al. (2015) find high SCC in the milk of the dairy cows received a short dry period length of 40 days. Besides, the path model revealed no significant correlation among different independent variables except the relationship between parity and days dry. The result could be due to the ability of the dairy cows to restore their body reserves declined with aging.

\section{Conclusion}

The study was concluded that the SCC was directly affected by lactation length, total and 305-day milk yields with the standardized beta load of $0.446,-0.173$, 0.367 , respectively, while it indirectly affected with total milk yield by a standardized beta load of 0.229 at $(\mathrm{p} \leq 0.001)$. The net standardized effects for the total milk yield upon the milk SCC were low due to the negative direct effect -0.173 , which neutralized with another positive indirect one 0.229 . 


\section{Data Availability}

The data sets used during the current study are available from the corresponding author on reasonable request.

\section{Declaration of Conflict of Interest}

The authors certify that no conflicts of interest exist.

\section{Acknowledgment}

The researchers acknowledge Dina farm staff, Giza, Egypt for letting us to collect the data, also the research team appreciated the help of the head manager of the animal production sector during conduction of our research methodology and data collection greatly.

\section{Funding}

This research did not receive any specific grant from funding agencies in the public, commercial, or any profit sector.

\section{Author's Contributions}

Ahmed Dawod, Sherif Shawky, Tamer M. AbdelHamid, Mohamed Fathalla and Ibrahim Abu-Alya: Conception, design and conduction of the study.

Ahmed Dawod, Ibrahim Abu-Alya and Said Fathalla: Acquisition of data.

Ahmed Dawod and Tamer M. Abdel-Hamid: Analysis and interpretation of data.

Ahmed Dawod, Sherif Shawky and Tamer M. Abdel-Hamid: Drafting the manuscript.

Mohamed Fathalla, Ibrahim Abu-Alya and Said

Fathalla: Critical revision of the manuscript.

All authors have read and approved the manuscript.

\section{Ethical Standards}

The study protocol and consent procedure were reviewed and approved by the Animal Care and Welfare Committee Ethics, Sadat City University, Egypt. The authors also assert that all procedures contributing to this work comply with ethical standards followed in animal researches.

\section{References}

Barrett, P., 2007. Structural equation modeling: Adjudging model fit. Personality Individual Differences, 42: 815-824.

DOI: 10.1016/j.paid.2006.09.018

Bradley, A. and M. Green, 2005. Use and interpretation of somatic cell count data in dairy cows. Practice, 27: 310-315. DOI: 10.1136/inpract.27.6.310
Carlén, E., E. Strandberg and A. Roth, 2004. Genetic parameters for clinical mastitis, somatic cell score and production in the first three lactations of Swedish Holstein cows. J. Dairy Sci., 87: 3062-3070. DOI: 10.3168/jds.S0022-0302(04)73439-6

Dohoo, I.R. and A.H. Meek, 1982. Somatic cell counts in bovine milk. Can. Vet. J., 23: 119-125.

Eyduran, E., T. Özdemir, K. Yazgan and S. Keskin, 2005. The effects of lactation rank and period on Somatic Cell Count (SCC) in milks of Holstein cows. YYU Vet. Fak. Derg., 16: 61-65.

Gonçalves, J.L., R.I. Cue, B.G. Botaro, J.A. Horst and A.A. Valloto et al., 2018. Milk losses associated with somatic cell counts by parity and stage of lactation. J. Dairy Sci., 101: 4357-4366. DOI: $10.3168 /$ jds.2017-13286

Harmon, R.J., 1994. Physiology of mastitis and factors affecting somatic cell counts. J. Dairy Sci., 77: 2103-2113. DOI: 10.3168/jds.S0022-0302(94)77153-8

Hu, L.T. and P.M. Bentler, 1999. Cutoff Criteria for Fit Indexes in covariance structure analysis: Conventional criteria versus new alternatives. Structural Eq. Model., 6: 1-55. DOI: $10.1080 / 10705519909540118$

IBM Corp, 2016. IBM SPSS Statistics for Windows, Version 24.0. IBM Corp, Armonk, NY.

Jia-Zhong, G., L. Xiao-Lin, X.A. Juan and X. Zhi, 2010. Relationship of somatic cell count with milk yield and composition in Chinese Holstein population. Agric. Sci. China, 9: 1492-1496.

Kadarmideen, H.N., 2004. Genetic correlations among body condition score, somatic cell score, milk production, fertility and conformation traits in dairy cows. J. Anim. Sci., 79: 191-201.

DOI: $10.1017 / \mathrm{S} 1357729800090056$

Kennedy, B.W., M.S. Sethar, A.K.W. Tong, J.E. Moxley and B.R. Downey, 1982. Environmental factors influencing test-day somatic cell counts in Holsteins. J. Dairy Sci., 65: 275-280. DOI: $10.3168 /$ jds.S0022-0302(82)82188-7

Khazanehei, H., S. Li, E. Khafipour and J.C. Plaizier, 2015. Effects of dry period management on milk production, dry matter intake and energy balance of dairy cows. Can. J. Anim. Sci., 95: 433-444. DOI: 10.1139/CJAS-2014-058

Kiiman, H., 1998. On somatic cell count in milk. AGRIS, 7: 39-40.

Laevens, H., H. Deluyker, Y.H. Schukken, L. De Meulemeester and R. Vandermeersch et al., 1997. Influence of parity and stage of lactation on the somatic cell count in bacteriologically negative dairy Cows. J. Dairy Sci., 80: 3219-3226.

DOI: $10.3168 /$ jds.S0022-0302(97)76295-7 
Lindmark, M.H., C. Branninga, G. Alden and M. Paulsson, 2006. Relationship between somatic cell count, individual leukocyte populations and milk components in bovine udder quarter milk. Int. Dairy J., 16: 717-727.

Nasr, M.A.F. and M.S. El-Tarabany, 2017. Impact of three THI levels on somatic cell count, milk yield and composition of multiparous Holstein cows in a subtropical region. J. Thermal Biol., 64: 73-77. DOI: 10.1016/j.jtherbio.2017.01.004

Nasr, M.A.F., 2016. The impact of crossbreeding Egyptian and Italian buffalo on milk yield and composition under subtropical environmental conditions. J. Dairy Res., 83: 196-201. DOI: $10.1017 / \mathrm{S} 0022029916000194$

Natzke, R.P., R.W. Everett and D.S. Postle, 1972. Normal milk somatic cell counts. J. Milk Food Technol., 35: 261-263.

Pirisi, A., A. Lauret and J.P. Dubeuf, 2007. Basic and incentive payments for goat and sheep milk in relation to quality. Small Rumin. Res., 68: 167-178.

Richoux, R., M. Boutinaud, P. Martin and V. Gagnaire, 2014. Role of somatic cells on dairy processes and products. Dairy Sci. Technol., 94: 517-538.

Schepers, A., T. Lam, Y. Schukken, J. Wilmink and W. Hanekamp, 1997. Estimation of variance components for somatic cell counts to determine thresholds for uninfected quarters. J. Dairy Sci., 80: 1833-40. DOI: $10.3168 /$ jds.S0022- 0302(97)76118-6

Sevi, A., L. Taibib, M. Albenzioa, A. Muscioa and G. Annicchiarico, 2000. Effect of parity on milk yield, composition, somatic cell count, renneting parameters and bacteria counts of Comisana ewes. Small Rumin. Res., 37: 99-107.

Sheldrake, R.F., R.J.T. Hoare and G.D. McGregor, 1983. Lactation stage, parity and infection affecting somatic cells, electrical conductivity and serum albumin in milk. J. Dairy Sci., 66: 542-547.

DOI: $10.3168 /$ jds.S0022-0302(83)81823-2
Steiger, J.H., 2007. Understanding the limitations of global fit assessment in structural equation modeling. Personality Individual Differences, 42: 893-98.

Tabachnick, B.G. and L.S. Fidell, 2007. Using Multivariate Statistics. 5th Edn., Allyn and Bacon, New York.

Teleb, D.F., F.H. Hafasa, Y. Azza, M. El-Baz and M.A. El-Sherbieny, 2014. Relationship between somatic cell count and udder health in Damascus goats. Egypt. J. Sheep Goat Sci., 9: 31-42.

Töpel, A., 2004. Chemie und physik der milch. Behr's Verlag GmbH and Co. KG, Hamburg DE, 756: 369-434.

Yalçın, C., A.Ş. Yıldız, S. Sarı̈zkan and A. Günlü, 2010. Producer profiles, production characteristics and mastitis control applications at dairy herds in Konya, Burdur and Kirklareli provinces, Turkey. Vet. J. Ankara Univ., 57: 43-48.

Yang, L., Q. Yang, M. Yi, Z.H. Pang and B.H. Xiong, 2013. Effects of seasonal change and parity on raw milk composition and related indices in Chinese Holstein cows in northern China. J. Dairy Sci., 96: 6863-6869.
Abbreviations
DF: The degree of freedom
DIM: Days in milk
DM: Dry matter
Kg: Kilogram
SCC: Somatic cell count
TMR: Total mixed ration 